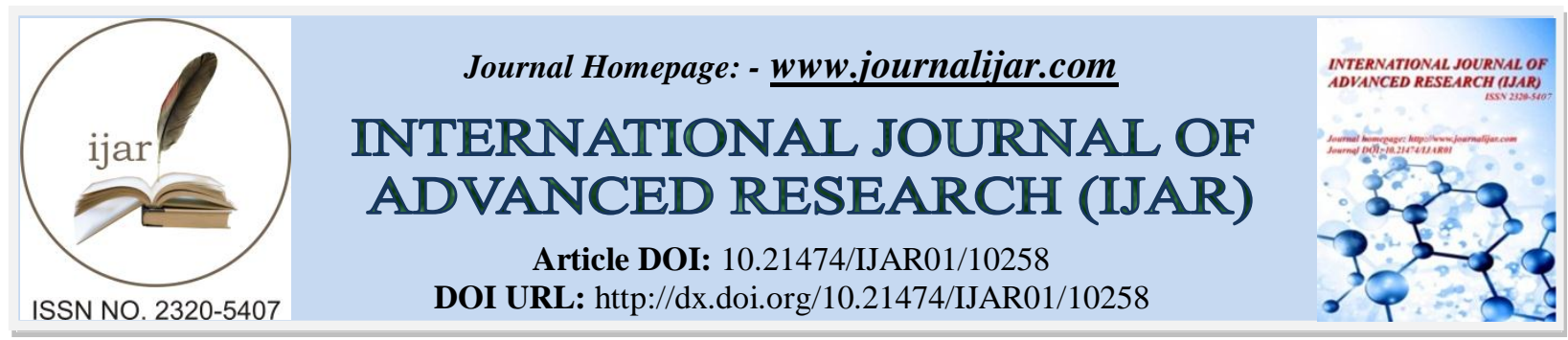

RESEARCH ARTICLE

\title{
EXPLORING THE CHANGE OF CORPORATE BRAND SUPPORT FROM THE CRISIS
} MANAGEMENT STAGE

\author{
Dr. Kao-Shan Chen \\ Department of Business Administration, Vanung University, No. 1, Vanneng Road, Zhongli District, Taoyuan City, \\ Taiwan.
}

\section{Manuscript Info}

.1.........................

Manuscript History

Received: 14 October 2019

Final Accepted: 16 November 2019

Published: December 2019

Key words:-

Brand Relationship Quality, Crisis Management, DOE, Brand Image

\section{Abstract}

The purpose of this paper is try to find out the effectiveness of crisis management by using design of experiment (DOE). Meanwhile, this paper is also to study the reflection by customers during different stage of crisis, such as before crisis, crisis happening and crisis recovery. The dimensions of brand relationship and reports related to food safety are accumulated to simulation the diffident stage of crisis management by using design of experiment. The result of this paper represent that among the stage of before crisis, crisis happening and crisis recovery is difference. This paper find out the most impact to customers is crisis happening as well which means most customers are affect the confidence with an enterprise by the affair of crisis, and the confidence of customers will be increased while a well treatment in the stage of crisis recovery.

Copy Right, IJAR, 2019,. All rights reserved.

\section{Introduction:-}

Food safety issues are a major issue that affects people's lives and health. According to statistics provided by the Department of Health and Welfare, food safety problems in recent years have shown an upward trend. Since 1979, Taiwan has suffered from "rice oil poisoning" and "poisonous wine" incidents, which has led to the rise of private consumer protection groups such as the Consumers' Education Foundation of the Republic of China, which kicked off the prelude to food safety and also hit the brand of well-known companies image.

Well-known food safety incidents, such as meat, plasticizer, black heart oil (oily copper chlorophyll, waste oil, feed oil, industrial oil). The Taiwan Consumer Protection Association has filed a group lawsuit against consumers. However, the judicial claims for food safety hazards need to be confirmed, making it easy for the government to indulge and punish the black heart. After 2011, Taiwan once again broke a series of major food safety incidents. The large number of food safety incidents and the emergence of "black heart food" for several consecutive years have caused concern in Taiwan society and even in the countries concerned. Taiwanese people are also worried about food safety, which has a series of follow-up effects, and food safety is also related to consumers' confidence in enterprises. Especially the well-known enterprises will make the brand image and consumption that have been established for a long time because of the food safety storm. The confidence of the people is shaken, and even may collapse in the hearts of consumers, causing an irreparable situation. Therefore, in the event of a crisis in the food safety storm, how can enterprises respond to the consumer's business at the end of the food safety storm? Whether there is any change in confidence is an important factor affecting the sustainable operation of the company.

Corresponding Author:- Dr. Kao-Shan Chen

Address:- Department of Business Administration, Vanung University, No. 1, Vanneng Road, Zhongli District, Taoyuan City, Taiwan. 
Therefore, this paper will discuss whether the consumer's confidence and loyalty to the company have any concern in the crisis of the company's crisis. The change is used as a reference for the treatment of enterprises in the face of crisis.

\section{Literature review:- \\ Brand Relationship:}

Blackston (1993) defines brand relationships as the process by which consumers interact with brands. He pointed out that the relationship between brand and consumer can be analogized to the relationship between two people. Duncan and Moriarty (1999) suggest that when a close brand relationship is established, customer stability and customer lifetime value can be enhanced. When a consumer purchases a product, a transaction relationship arises; in this transaction relationship, the consumer spends time, money, and effort to exchange the functions, utilities, or other benefits brought by a certain brand product, and create a difference in different transaction relationships. The value of the relationship; the value of the relationship includes the relationship of interest (the benefit derived from the product), the cost of the relationship (the cost of purchasing the product), and are subjective (Liljander and Strandvik, 1995). In addition, the social exchange theory believes that the formation of interpersonal relationships is because the benefits derived from the relationship outweigh the costs, that is, the relationships arising from economic interests; therefore, the relationship interests are regarded as important variables affecting the relationship, and the relationship interests are To "consumers and businesses in a long-term relationship, in addition to the core services, consumers receive other benefits from the business" (Gwinner, Gremler and Bitner, 1998). The establishment of brand relationship is a good way for enterprises to create brand equity, and it is to enable consumers to experience good product or service quality and enhance their satisfaction (Philip Kotler, 2001).

\section{Brand relationship quality:}

Brand relationship quality (BRQ) was proposed by Fournier (1994). She developed the 15 brand relationship patterns generated by the interaction between brand and consumer from the concept of interpersonal relationship, and believed that consumers interacted here. Brands should be seen as partners in relationship development. The brand relationship can define the interaction process of the relationship established between the customer and the brand in the process of consumption, so it can be known that in this process, the brand is not only passive to let consumers have some opinions on it, but An active role to convey certain ideas to consumers, and also to anthropomorphize the brand to have human attributes. Gifford (1997) argues that brand relationship is a viable solution. The goal of brand relationship is that consumers regard brand as a partner (brand-as-partner), and the process of brand relationship is interactive. If the brand can be used properly The concept of relationship can learn from consumers' purchasing psychology and demand, and can obtain useful information from consumers' purchase behavior. Therefore, the concept of brand management establishing good brand relationship is to increase brand strategy performance and maintain customer loyalty. When Bengtsson (2003) commented on brand relationships, he also believed that consumers should anthropomorphize brands. The relationship between the two is like a friend in interpersonal relationships. For example, you may be just ordinary friends with some people, and others. People are close friends and have different feelings for everyone, so the relationship between them is different.

\section{Crisis Management:}

"Crisis" is "crimein" in ancient Greek. It has the meaning of Divide or Discriminate, Sift and Decide. It has the characteristics of "important key moments". "Crisis" is a threatening situation or event caused by environmental factors inside and outside the organization, which threatens the survival and value of individuals and organizations. This paper is defined as: "Crisis is caused by internal and external factors of the organization, and has immediate and serious threats to the organization." The development phase of the crisis. Fink (1986) divided the trend after the crisis into three phases, as described below:

1. Incubate stage. When the crisis is about to happen, it will reveal all kinds of clues. It is interoperable with the concept of the butterfly effect. It emphasizes the importance of squatting. Any phenomenon hides specific meaning. Small things that are inconspicuous should not be easily overlooked, otherwise they will cause more loss or damage, therefore this stage is also called the "warning period"..

2. Acute stage. When the crisis has reached the critical point, it cannot be stopped. At this time, it will erupt like a river break or a volcanic eruption, if no effective measures are taken immediately. Dealing with it will result in unpredictable and expected loss or damage.

3. Recovery stage. It means that the losses or injuries caused by the crisis have been completely solved, and the crisis is reviewed and improved, the lessons learned, and how to deal with the crisis is established, and a crisis management mechanism is established. 


\section{Experimental design:}

Experimental research can be said to be the most important research method in the field of science. Especially when psychology entered the era of scientific psychology, experimental design became the mainstream method of psychological research. In fact, the experimental method is not only the main research orientation of psychology, but also the research strategy used by other subject researchers to explore the effect of a particular method or to carry out different operational processes. The experiment is a scientific attempt by researchers to find evidence of the causal relationship between human things (Cook \& Campbell, 1979), which is a set of scientific objective programs of "taking action" and "observing results". (Babbie, 2004). Experimental design refers to a set of plans for arranging subjects into experimental situations and conducting statistical analyses (Kirk, 1995).

\section{Research Methods:-}

\section{Theoretical framework}

The study mainly adopts the experimental design method and uses the variance analysis to make hypothesis tests. The experimental design method was originally used in the study of psychology. It is a research method that manipulates a certain variable under controlled conditions to examine its influence on other variables. The experimental design method is mainly used for the verification of causality. In recent years, research on marketing has begun to explore the consumer behavior under certain control conditions by means of the mirror design method, which is to explore the causal relationship between the independent variables and the dependent variables.

Analysis of Variance (ANOVA) is a test invented by R.A. Fisher for the determination of whether there is a significant difference in the mean of two or more samples. The data of the Institute is fluctuating due to various factors. The causes of fluctuations can be divided into two categories: uncontrollable random factors, and controllable factors that affect the outcome of the research squadron.

\section{Experimental simulation scenario}

This experiment is a single-factor three-level experimental design, in which the three levels included in the crisis stage of the self-variable brand are the incubation period, the outbreak period and the recovery period. The experimental design was an independent group to avoid contamination of the experimental results caused by repetition and fatigue. Therefore, "Yimei Food Corp.", which is well known company among consumers in Taiwan, was selected as the experimental object. In order to reduce the shortcomings of the low externality of the experimental method, the experimental design selected the brand crisis of "Yimei Food Corp." in the plasticizer storm, and in order to obtain better experimental results, some details were slightly modified during the description of the situation. At the same time, in order to eliminate the tester's effectiveness in destroying the experimental operation due to the well-known food safety storm incident, the question "Do you know the food safety incident of Yimei Puffs" was designed in the questionnaire, and the subjects who are familiar with the incident were deleted. . The context of the evolution of the brand crisis is described in the following table:

Table 1:- Situational simulation of the evolution stage of the brand crisis.

\begin{tabular}{|l|l|}
\hline Brand crisis evolution stage & Situational simulation description \\
\hline Incubate stage & $\begin{array}{l}\text { In December 2011, a female college student bought Yimei puff, and after eating a } \\
\text { strange smell, she saw that there was a mouse body about } 10 \text { centimeters in the } \\
\text { package, which scared her to vomit on the spot. The news spread quickly on the } \\
\text { Internet and received a lot of attention from users. However, the authenticity of the } \\
\text { news has not been confirmed by the relevant owners and government agencies. } \\
\text { Uses also said that this message is difficult to distinguish between true and false. }\end{array}$ \\
\hline Acute stage & $\begin{array}{l}\text { In } 2013 \text {, Yimei Longtan Factory was reported to use expired raw materials. After } \\
\text { investigation, it was found that a batch of soy protein isolates that expired in } \\
\text { August } 2010 \text { were used in the puffs produced by the factory. Although an } \\
\text { emergency check of } 120,000 \text { boxes was estimated, there are still about } 36 \text { cases. A } \\
\text { total of } 4.32 \text { million boxes of } 10,000 \text { boxes have flowed into the market. } \\
\text { The Taoyuan County Health Bureau issued a fine of NT } \$ 150,000 \text { for this purpose, } \\
\text { and the Taoyuan District Inspection Office believed that the Longtan Plant was } \\
\text { suspected of using about } 10,000 \text { kilograms of expired raw materials. From } \\
\text { September } 2010 \text { to August } 2012, \text { it repeatedly invested in expired raw materials. . } \\
\text { After the quality control personnel found out, they worried about the impact of the }\end{array}$ \\
\hline
\end{tabular}




\begin{tabular}{|l|l|}
\hline & $\begin{array}{l}\text { company's application for ISO9001 and ISO22000 certification, and then } \\
\text { exchanged the production records. In September 2013, the prosecution sued the } \\
\text { relevant four people for the crime of forgery. } \\
\text { As for the sample of the same batch that has been retained, it has been confirmed } \\
\text { that it does not contain mold and toxins. Because it cannot prove that it is harmful } \\
\text { to health, it does not meet the requirements of the Food Sanitation Management } \\
\text { Law, and the prosecutor will sign it. }\end{array}$ \\
\hline Recovery stage & $\begin{array}{l}\text { After the disclosure of the } 5 / 20 \text { incident, Yimei took the initiative to remove the } \\
\text { small puffs. } \\
5 / 21 \text { Issue the first statement, explain the truth to the public and apologize. } \\
5 / 22 \text { Issue a second statement and apologize again to the public and decided to } \\
\text { donate } 15 \text { million NT dollars to consumers related public welfare groups. } \\
5 / 26 \text { Yimei announced that it will receive a full } 10 \% \text { discount on the } 6 \text { th to } 12 \text { th } \\
\text { threshold. } \\
5 / 31 \text { Yimei took the initiative to send all products for inspection and issued a } \\
\text { statement. Yimei's full range of products are free of maleic acid, and the } \\
\text { inspection report of all products is published on the official website }\end{array}$ \\
\hline
\end{tabular}

\section{Research Results:-}

\section{Sample data analysis:}

This study adopts a random sample survey. A total of 400 questionnaires were sent out, 380 questionnaires were collected, and the recovery rate was $95 \% .358$ valid questionnaires, the effective rate was 94.2. \%. The valid sample structure of this study is described in the following table:

Table 2:- Descriptive statistics.

\begin{tabular}{|l|l|}
\hline $\begin{array}{l}\text { Classification } \\
\text { criteria }\end{array}$ & Feature distribution \\
\hline gender & $55.7 \%$ of male and $44.3 \%$ of female \\
\hline age & $44.3 \%$ under the age of $20,38.6 \%$ from 21 to $30,10.8 \%$ from 31 to 40, and $6.3 \%$ from 41 to over \\
\hline marriage & Unmarried accounted for $70.3 \%$ and married accounted for $29.7 \%$ \\
\hline Career & $\begin{array}{l}\text { Students accounted for } 28.7 \%, \text { industry and commerce accounted for } 24.6 \%, \text { manufacturing } \\
\text { accounted for } 23.9 \%, \text { military and public education accounted for 10.8\%, service industry } \\
\text { accounted for } 8.2 \%, \text { others accounted for } 9.2 \%\end{array}$ \\
\hline $\begin{array}{l}\text { monthly } \\
\text { income }\end{array}$ & $\begin{array}{l}19.5 \% \text { below } 20,000 \text { NT dollars, 37.8\% below 20,000 40,000 NT dollars, 42.7\% above 40,000 NT } \\
\text { dollars }\end{array}$ \\
\hline
\end{tabular}

\section{Reliability analysis:}

Nunnally (1978) considered Cronbach's $\alpha$ greater than 0.7 to be an acceptable standard. Zhou Wenxian (Min 93) pointed out that Cronbach's $\alpha$ has a minimum acceptable range of 0.5 to 0.6, and Cronbach's $\alpha$ value judges the criterion of reliability: $\alpha<0.35$ for low confidence; $0.35<\alpha<0.7$ for medium confidence; $\alpha>0.7$ On behalf of high confidence, in practice, $\alpha \geqq 0.6$, you can declare the reliability of the questionnaire subject is acceptable. The results of the reliability analysis of each facet factor in this study are shown in the table below. It is known from the table that the Cronbach's $\alpha$ value of all factor facets is higher than 0.6, which is an acceptable range. Therefore, the reliability of the facet of this study has reached a reasonable range.

Table 3:- Reliability Analysis.

\begin{tabular}{|l|l|l|}
\hline Perspectives & Cronbach's $\alpha$ value & test result \\
\hline $\begin{array}{l}\text { Brand commitment and brand } \\
\text { relevance }\end{array}$ & 0.942 & High reliability \\
\hline Brand ownership and brand attention & 0.927 & High reliability \\
\hline $\begin{array}{l}\text { Brand familiarity and brand } \\
\text { understanding }\end{array}$ & 0.871 & High reliability \\
\hline Brand trust and brand respect & 0.870 & High reliability \\
\hline
\end{tabular}




\section{Validity analysis:}

Whether the correlation matrix is factored or not can be judged from the Kaiser-Meyer-Olkin measure proposed by Kaiser and Rice (1974). The closer the KMO value is to 1, the better the KMO value of this study is.

Table 4:- KMO and Bartlett test table.

\begin{tabular}{|l|l|l|l|l|}
\hline Perspectives & Validity & Bartlett's spherical test & df & Test result \\
\hline Brand commitment and brand relevance & 0.939 & 4007.363 & 253 & High validity \\
\hline Brand ownership and brand attention & 0.809 & 395.840 & 3 & Medium validity \\
\hline Brand familiarity and brand understanding & 0.802 & 330.068 & 3 & Medium validity \\
\hline Brand trust and brand respect & 0.938 & 631.425 & 3 & High validity \\
\hline
\end{tabular}

\section{Comparative analysis of situations in different crisis stages:}

The analysis of the variance of brand relationship quality at different stages showed that there was a significant difference in the quality of the brand relationship between the three phases of the crisis (latency, outbreak, and recovery) $(\mathrm{F}=11.82, \mathrm{p}=0.000<0.05)$. Comparing the averages of the various stages of the crisis, it can be seen that the period of the crisis is the lowest, and the recovery period is slightly higher than the incubation period. Therefore, if the manufacturer's disposal is appropriate in the event of a crisis, the consumer's perception of the corporate brand will be somewhat Improve, even higher than the original view 。

\section{Comparative Analysis of Brand Relationship and Brand Image:}

This chapter will focus on brand relationships and brand image (brand commitment and relevance, brand ownership and attention, brand familiarity and understanding, brand trust and respect) to enable more content for each facet. Do an in-depth understanding.

\section{Brand commitment and relevance:}

From the analysis of the variance of brand promise and relevance, the results of brand commitment and correlation in the three stages of crisis incubation period, crisis outbreak period and crisis recovery period are significantly different $(\mathrm{F}=11.82, \mathrm{p}=0.000<0.05)$. Comparing the averages of each stage, it can be seen that the period of crisis is the lowest, and the recovery period is slightly higher than the incubation period. Therefore, if the manufacturer's disposal is proper in the event of a crisis, the consumer's brand promise and relevance to the company will be Higher evaluation.

\section{Brand affiliation and brand attention:}

The analysis of the variance of brand attribution and attention shows that there are significant differences in brand attribution and attention in the three stages of crisis incubation period, crisis outbreak period and crisis recovery period $(\mathrm{F}=3.41, \mathrm{p}=0.033<0.05)$. Comparing the averages of each stage, it can be seen that the period of crisis is the lowest, and the recovery period is slightly higher than the incubation period. Therefore, if the manufacturer's disposal is proper in the event of a crisis, the consumer's brand promise and relevance to the company will be Higher evaluation.

\section{Brand familiarity and brand understanding:}

The results of the analysis of the variance of brand familiarity and understanding showed that there was no significant difference in brand familiarity and understanding between the crisis incubation period, the crisis outbreak period and the crisis recovery period $(\mathrm{F}=1.68, \mathrm{p}=0.187>0.05)$. Comparing the averages of each stage, it can be seen that the crisis incubation period is the lowest, and the crisis outbreak period is almost the same as the crisis recovery period, indicating that consumers' familiarity and understanding of the brand will not be affected by different stages of the crisis.

\section{Brand trust and brand respect:}

The analysis of the variance of brand trust and respect shows that there is no significant difference between brand trust and respect in the three stages of crisis incubation period, crisis outbreak period and crisis recovery period $(\mathrm{F}=0.00, \mathrm{p}=0.999>0.05)$. Comparing the averages of each stage, it can be seen that the crisis incubation period, the crisis outbreak period and the crisis recovery period are almost the same, indicating that consumers' trust and respect for the brand will not be affected by different stages of the crisis. 


\section{Conclusions:-}

According to the analysis of the questionnaire data, the results are summarized as follows:

1. The analysis of the variance of brand relationship quality at different stages showed that there were significant differences in the brand relationship quality of the three stages (latency period, outbreak period, recovery period) $(\mathrm{F}=11.82, \mathrm{p}=0.000<0.05)$. The average recovery period $(3.365)$ is significantly greater than the crisis incubation period (3.277) and the crisis outbreak period (3.251). It shows that in the recovery period of the crisis, if the enterprise is properly handled after the crisis, it will turn the crisis into a turn for the enterprise. Enter another business event.

2. The brand relationship quality of the brand crisis is the lowest, and the brand quality of the recovery period is the highest:

3. The outbreak period of brand crisis is the lowest stage of brand relationship quality in the process of crisis evolution, in which brand commitment and relevance are greatly reduced. This is because when the brand crisis breaks out, the crisis situation is further aggravated by consumers. The severity of the crisis is strong, and the "negative message effect" formed by the media's in-depth reports has made consumers pay more attention to the brand crisis. At the same time, the pressure from society and public opinion has made consumers reluctant to try to buy the brand during the crisis.

4. Recovery period of brand crisis is the highest quality of brand relationship in the process of crisis evolution. The brand commitment and relevance and brand ownership and attention are greatly improved, indicating that consumers' trust in the brand is gradually restored. They would like to believe in the brand's message and the future development of the brand. When the brand crisis occurred, the crisis situation was well controlled due to the proper handling of the corporate crisis. Therefore, the negative news about the brand during the crisis broke out, and the pressure of public opinion felt by consumers also decreased. People also gradually regain confidence in the brand due to the relationship between the attitude of the company and time.

5. According to the various stages of brand commitment and relevance, brand ownership and attention, brand familiarity and understanding, brand trust and respect, it can be seen that during the crisis incubation period, crisis outbreak period, and crisis recovery period After comparing the three stages, there are significant differences.

\section{References:-}

1. Babbie, E., (2004), "Laud Humphreys and research ethics", International Journal of Sociology and Social Policy, 24(3): 12-19.

2. Bengtsson A., (2003), Towards a crigique of brand relationships. Advances in Consumer Research, 30(1): 154158..

3. Blackston, M.,(1993)., "Beyond Brand Personality: Building Brand Relationships." in Brand Equityand Advertising: Advertising's Role in Building Strong Brands, ed. David Aaker and Alexander Biel.Hillsdale. New Jersey: Erlbaum, 113-124.

4. Cook, T. D. and Campbell, D. T..(1979), "Quasi-Experimentation: Design \& Analysis Issues for Field Settings". Boston: Houghton Muffin Company, 37- 94.

5. Dobni, D. and V. A. Zeithaml.,(1990)., "In Search of Brand Image: A Foundation analysis." In Advancesin Consumer Research, Vol. 17 No.1 edited by M. E. Goldberg, G. Gorn, and R. Pollay, UT:Association for Consumer Research, 110-119.

6. Dodds, W. B., K. B. Monroe and D. Grewal., (1994)., "Effects of Price, Brand, and Store Informationon Buyers' Product Evaluation.” Journal of Marketing Research, 28(8), 307-319.

7. Duncan, T. and S. Moriarty., (1999)., "Brand Relationships Key to Agency of the Future." Advertising Age, 18(10), 44-51, 1999.

8. Fink, Steven., (1986), Crisis Management: Planing for the Inevitable. NY: American Management Association.

9. Fournier, S.. (1994), A consumer-brand relationship framework for strategic brand management, Ph.D. Dissertation, FL: University of Florida.

10. Gifford, D., Jr., (1997), Brand management: Moving beyond loyalty. Harvard Business Review, 75(2), 9-1.

11. Gwinner, K. P., D. D. Gremler, and M. J. Bitner.,(1998), "Relational Benefits in Services Industries:The Customer's Perspective." Journal of the Academy of Marketing Science, 26(4), 101-114.

12. Garretson, J. A. and K. E. Clow.,(1999), "The Influence of Coupon Face Value on Service Quality Expectations, Risk Perceptions and Purchase Intentions in the Dental Industry." The Journal of Services Marketing, 13(1), 59-72.

13. Kirk, R. E.(1995), "Experimental design: Procedures for the behavioral sciences (3rd ed.)". Pacific Grove, CA: 
Brooks.

14. Philip Kotler, Kevin Lane Keller, Ang Swee Hoon, Leong Siew Meng, Tan Chin Tiong., (2001), Marketing Management: An Asian Perspective -5th Edition. McGraw•Hill Publishing, New York.

15. Liljander and Strandvik,(1995), "The Nature of Customer Relationships in Services." Advances in Services Marketing and Management, 4, xxiii-xxiv.

16. Randall G.,(1997), Do Your Own Market Research, 1st Edition, California: Kogan Page Ltd,

17. Richardson, P. S., A. S. Dick, and A. K. Jain, (1994), "Extrinsic and Extrinsic Cue Effect on Perceptionsof Store Brand Quality." Journal of Marketing Research, 58(4), 28-36.

18. Zeithaml, V. A., (1998), "Consumer Perceptions of Price, Quality and Value: A Means-End Model and Synthesis of Evidence." Journal of Marketing, 52, 2-22. 